\title{
Vernacular Education in India: British Education Policy in 1840
}

\author{
Sumeet Tanwar \\ India \\ *Corresponding Author: Sumeet Tanwar, India \\ Abstract: This article proposes to investigate the areas of contestation and negotiation in the process of the \\ implementation of the plan adopted by the General Committee of Public Instruction in 1840's to attach \\ vernacular classes to the English departments and seminaries under its control in the North Western and \\ Central Provinces. This scheme was launched when English seminaries failed to attain any considerable \\ success. Under this new scheme the principle English texts were translated in the vernacular languages of \\ India. In the Central and North Western Provinces Hindi and Urdu were chosen for translation from English.
}

\section{INTRODUCTION}

The emphasis on vernacular education emerged in 1840's, when the General Committee of Public Instruction (GCPI) at Calcutta began to review its policy of diffusing English education among the Indians. ${ }^{1}$ On $25^{\text {th }}$ April 1840 , the secretary to the Education Committee forwarded the minutes of the Governor General dated Delhi, $24^{\text {th }}$ November 1839 to all the local committees. Paragraph 38 of the minutes the Governor General stated that,

Their Government of Bombay and Madras should be specially invited to cooperate through the bodies charged with the control of Public Instruction under their superintendence in the common object of aiding the preparation of a useful and comprehensive set of class books to be afterwards rendered into the vernacular tongues of the several provinces. In order to arrive at the speediest and fullest on this important subject I am directed to request that you will have the goodness to forward us with as little delay as possible a list of works that have been or may now be translating into the vernacular languages of your Presidency, the price of translating and printing them and your opinion as to their utility in the education of the natives with any remarks which you consider useful in carrying out the wishes of the Governor General. ${ }^{2}$

In response to this order all the presidencies responded swiftly. In the Presidencies of Bengal, Bombay and Madras the work of translating English book into the vernacular was set in motion by the respective committees of public instruction. ${ }^{3}$

The local committees of public instruction in Central and North Western Provinces were directly under the control of GCPI at Calcutta and GCPI invited response from person engaged in native education in these provinces. ${ }^{4}$ The English Seminary first was attached to the Benares College in 1830 but it could not meet with any considerable success because the educated classes in Benares preferred Persian over English for practical reasons. To persuade native gentry and educated classes towards the study of English a Persian class was attached to the English seminary in October 1832. George

1 See, Short Essays and Reviews on the Educational Policy of the Government of India, As Expounded by the Hon. Summer Maine, D.C.L, Sir Donald Friel Macleod, C.B, K.C and the Late Lord Macaualy. Calcutta: The Englishman Press. 1886, 124; Appendix I, 1-7. For recent studies on British education policy of the given period, see, Zastoupil, Lynn. Moir, Martin. Ed. The Great Indian Education Debate: Documents Relating to the Orientalist-Anglicist Controversy 1781-1843. (London: Routledge. 2013)

2 WBSA (50) General Committee of Public Instruction Vernacular Classes 1840-1842. Vol. 6 (A), 133.

3 For list of books prepared at three presidencies, See, West Bengal State Archives (50) General Committee of Public Instruction Vernacular Classes 1840-1842. Vol.6 (A), 373. 
Nicholls after taking charge of English Seminary in 1835 replaced the Persian class attached to the seminary with vernacular classes of Hindi and Urdu. Nicholls's idea behind the introduction of vernacular classes in English Seminary was that,

If attention to the vernacular dialects be encouraged it may be excepted that at some future period those who are studying English will translate a portion of learning they acquire into the native language thus enriching them and exciting a desire amongst their countrymen for an acquaintance with a language which contains so much to enlarge the minds and to enlighten the views of those who study it. ${ }^{5}$

The same model of attaching vernacular classes to the English seminaries was followed in schools, stationed at Allahabad, Gazipur, Azimgarh, Gorakpur, Farruckabad in North-Western Provinces (United Provinces); Jabalpur and Sagar in Central Province. ${ }^{6}$

The school at the British station in Sagar, headed by Rao Krishna Rao (son of the hereditary Diwan of the principality of Sagar) had three independent departments of Persian, Marathi and Hindi, previous to the establishment of English seminary at the school in the year 1835. The Sagar School was governed by LCPI which in principle was directly subordinate to GCPI at Calcutta. Though in 1830's and 1840's before the establishment of railroads, telegraphs this station school at Sagar enjoyed an indirect autonomy and as the head of the school was practically independent in his activities. Joseph Stevens Blackmister of Boston, possibly a missionary who met Rao Krishna Rao at Calcutta, in his letter dispatched from Boston, described the task undertaken by his friend Rao Krishna Rao of imparting European scientific education among the native masses at such a distant station in terms of a combat, "where the contest is with an old and deep rooted prejudice sanctified in the eyes of men by antiquity'.

The English seminary at the Sagar School was without any teacher and getting teachers acquainted to teach English to the pupils in this distant station school was difficult since European teachers preferred urban centres. To make English classes functional Rao Krishna Rao, managed to take on board one English master Mr. Derozio who accompanied him from Calcutta to teacher the rudiments of English literature at Sagar School. After few days of residence at the Sagar station, Mr. Derozio decided to move back to Calcutta, as he could not find a safe footing at the Sagar Station. ${ }^{8}$ His departure resulted in the appointment of an incompetent master Ram Chunder to teach English language and rudiments of European scientific knowledge to the students of the school. In 1837 the number of pupil in English seminary was 28, while the Hindi department of the school had 122 pupils divided into six classes. The studies of the most advanced pupils in Hindi department consisted of Subha Bilas, geography, arithmetic and astronomy. The school was suffering from the lack of books; hence some of the first books in Hindi were compiled by the initiative of Rao Krishna Rao. The list of Hindi books prepared at the schools was as follows: -

\begin{tabular}{|l|l|}
\hline Hindi Books at Sagar School & Copies \\
\hline The Hindee Primer & 400 copies \\
\hline $\begin{array}{l}\text { Mr. Rowe's Hindustani Spelling Book third edition } \\
\text { first printed in } 1833\end{array}$ & 300 copies \\
\hline $\begin{array}{l}\text { Fables in Hindustanee for the use of schools. Second } \\
\text { edition }\end{array}$ & 100 copies \\
\hline Betal Pachessa & 20 copies \\
\hline Pearson's Geography and Astronomy & 30 copies \\
\hline Treatise on the Globe & 50 copies \\
\hline Arithmetic & 50 copies \\
\hline
\end{tabular}

5 Nicholls to Sutherland, WBSA 11 th January 1834 to $23^{\text {rd }}$ December 1837 Vol. 9 part 2. Sl.no 13/2. 277. LCPI at Benares was repeatedly making this observation that there were very few Hindustani pupils in the College who can write their own language with anything like orthographic or syntactical correctness.

6 Benares College established in 1797 soon emerged as the centripetal institution for the North Western and Central Provinces.

7 WBSA, Sagar School, 157

8 Not the Derozio of Hindoo College, Calcutta. 
A globe for the use of the students of Hindi prepared by Rao Krishna Rao in 1836 has been listed below.

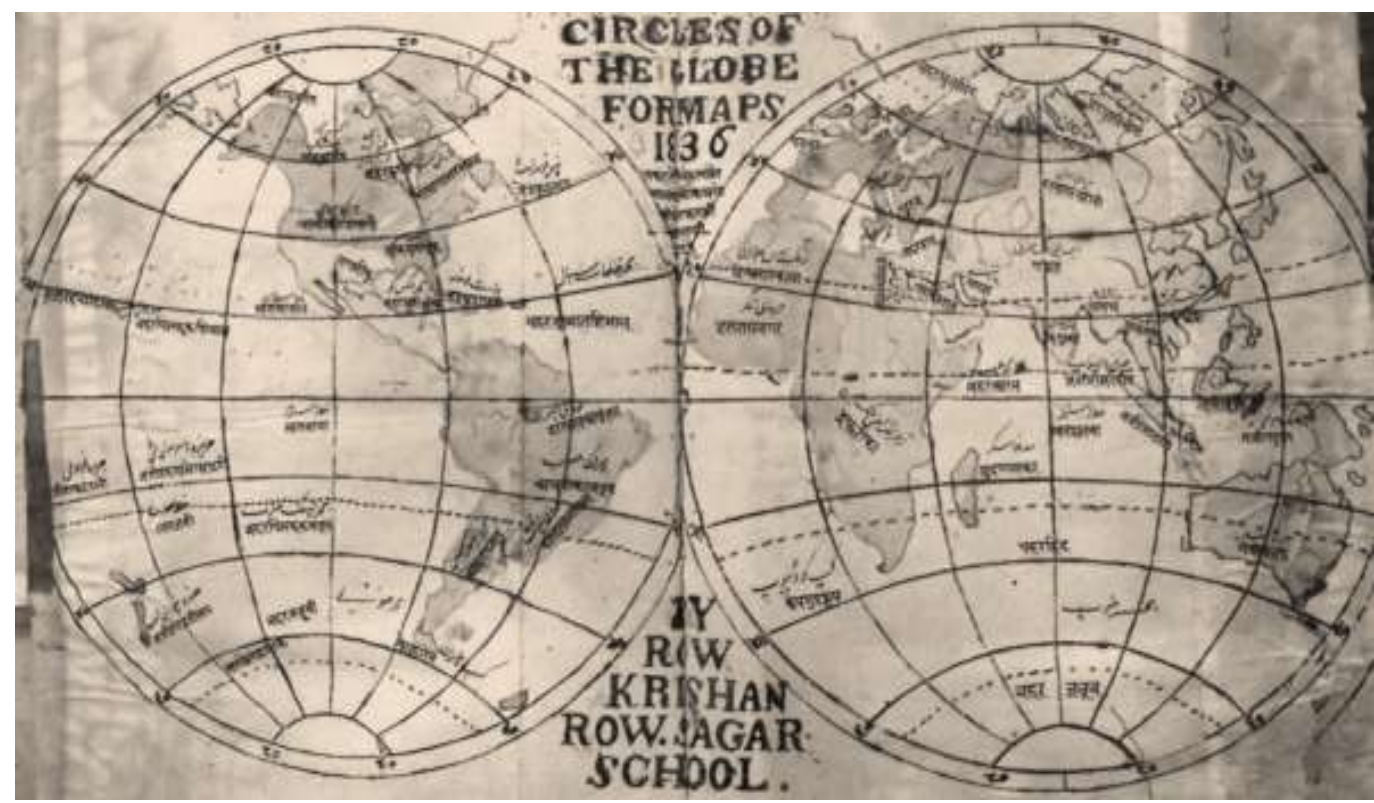

Fig1.

The students of Hindi taught by Ram Chunder and Rao Krishna Rao at the school perpared texts in Hindi on astronomy, geography and mathematics. The name of the students who compiled these texts were Omrao, Veju Marathe, Bharo Prasad. These Hindi texts in both verse (using mataric meter of Chupaee, Saviya etc) and prose were based on the knowledge of the European science as understood by the compilers. The lack of complete information was also admitted as one of the student noted that the principle countries of Europe were not known to him. These texts were intended to teach the students of Hindi, that the earth rotates around the sun etc, without taking any notice of the astronomical and geographical foundling based on the Siddhanta texts popularly studied by the educated classes especially the Pandits of this region. ${ }^{9}$ The central argument that established the superiority of European scientific knowledge over the Siddhantic texts was that of the brave European sailors, who had revolved around the earth in their ships and consequently proved that the earth is round. ${ }^{10}$ These independent activities of defective translations of the knowledge contained in the English books alarmed the GCPI and on September 1840 the following list of vernacular books printed at the Agra School Book Society were supplied to the school.

9 By the region I mean Maratha, Central Provinces and Benares where Siddhanta texts were popularly studied till the first half of the $19^{\text {th }}$ century. However the geographical imagination of the world contained in a set of Buddhist and Puranic texts was popular throughout Asia or Jambudvipa. Until the nineteenth century, even the Japanese Buddhists envisioned a world system in which India was the centre, China was located at the periphery and Japan was even more isolated territorial entity. In the Siddhantic model of the cosmos the earth is a fixed, non rotating sphere at the centre of a series of interesting spheres on which the sun, moon, and the various planets and stars revolve around the earth. In this model the planets are ranged above the earth in this order: Moon, Mercury, Venus, Sun, Mars, Jupiter, Saturn, and all the stars. In this model the diameter of the earth is calculated to be about 1600 yojanas. See, Tensen Sen. Ed. Buddhism Across Asia. New Delhi: Manohar Publisher and Distributors. 2014, 259; and Axel Michaels. The Pandit

Traditional Scholarship in India. (New Delhi: Manohar Publishers \& Distributors, 2001), 81.

10 The establishment of the superiority of European authorities in the $19^{\text {th }}$ century was not a phenomenon restricted only to India. In Japan the accumulation of western geography, especially its notions of a spherical earth rotating around the sun, presented a powerful challenge to traditional Buddhist representation. Japanese authors, however, chose to integrate western elements and information within old geographical framework as much as possible. The Japanese began to know regions not covered by Xuanzang or by any other Buddhist text known to them. See, Tensen Sen. Ed. Buddhism Across Asia. New Delhi: Manohar Publisher and Distributors. 2014, 266-7. 


\begin{tabular}{|l|l|}
\hline Books in Persian Character & Books in Nagree Character \\
\hline History Russell's Translated in Urdu & $\begin{array}{l}\text { Bhugol Darpan in Hindee } \\
\text { Brief Account of Solar System } \\
\text { First Geography of Natives in Urdu } \\
\text { Urdu Spelling Book }\end{array}$ \\
& English Irregular and Depart Verbs \\
\hline
\end{tabular}

The overtly cautious attitude of the GCPI at Calcutta in regard to outline the fault the Siddhantic system of astronomy and geography were based on the feedback it received from two important authorities on the education of natives in the North Western and Central Provinces, Lancelot Wilkinson and H.T Prinscep. ${ }^{11}$ First book of Hindi Bhugol Darpan: A Comparison of the Puranic and Siddhantic Systems of Astronomy With that of Copernicus by Onkar Bhut of Sehore, published under the authority of Agra School Book Society, Agra Press, 1841 was a very carefully compiled book. ${ }^{12}$ The book was in the form of a dialogue between the teacher and student, comparing the Copernican notions with the Siddhanta texts of Bhaskarcharya, where the author submitted to the authority of European knowledge over the geography of the world. The process of integration of western knowledge with Siddhantic texts was taken further by another Pandit of Sehore, Bapu Deva Sastri. ${ }^{13} \mathrm{He}$ joined Benares Sanskrit College in 1842 as a professor of natural philosophy. ${ }^{14}$

In January 1841, an observer from Calcutta visited the school and was surprised by the activities of this school in advancing the native education with English and vernacular at 'this distant station'. After his return to Calcutta, GCPI on $29^{\text {th }}$ January 1841 directed the LCPI, in charge of the Sagar School to make certain changes in the management of the school, to place it in accordance with the larger plan of the native education adopted by GCPI. ${ }^{15}$ The proposed changes for the school were sanctioned by the Governor General in Council. In consequence to these changes the Hindi department of the school as a separate department was discontinued. Rao Krishna Rao was relieved from his situation as Superintendent of the Sagar School and his salary was reduced to that scale proposed for head vernacular teacher (Rs 80) and he was removed to Jabalpur. ${ }^{16}$ The vernacular department of the school

11 See, The Best Means of Promoting Vernacular Education. WBSA (50) General Committee of Public Instruction Vernacular Classes, 1840-1842. Vol. 6 (A), 141-191.

${ }^{12}$ Sehore was an important education centre located in Central Provinces where the collusion between European scientific knowledge and Sanskrit sources occurred in the first half of the $19^{\text {th }}$ century, under the supervision of Lancelot Wilkinson. For Wilkinson's intervention among the Pandits and his activities at Sehore Sanskrit Pathasala, see, Richard Fox Young. "Receding From Antiquity: Indian Responses to Science and Christianity On The Margins Of Empire". 1997, Kokusaigaku-Kenkyu 16 (Meji Gakuin Ronso 595), 241-74; Micheal S. Dodson. Orientalism, Emipre and National Culture India, 1770-1880. (New York: Palgrave Macmillian,2007); Joydeep Sen. Astronomy In India (New York: Routledge, 2016). For his political activities see, Shaharyar M. Khan. A Dynasty Of Women Rules In Raj India. (London: I.B Tauris Publishers. 2000)

${ }^{13}$ For life and works of Bapu Deva Sastri see, Baldeva Upadhyaya. Kasi Ki Panditya Parampara. (Varanasi: Visvavidyalaya Prakasan. 1983), 187-199 (in Hindi)

${ }^{14}$ The appointment was made on the recommendation of Lancelot Wilkinson, according to whom Bapu Deva Sastri was perfectly acquainted with the Siddhants of Bhaskarcharya and a perfect genius in solving algebraic questions of all sorts- geometry, trigonometry plain and spherical i.e. the disciplines comprised under natural philosophy. In the words of German philosopher Hegel, the Newtonian physics was called natural philosophy in Great Britain. "In England this stills the usual signification of the term philosophy. Newton continues to be celebrated as the greatest of philosophers: and the name goes down as far as the pricelist of instrument-makers. All instruments, such as the thermometer and barometer which do not come under the special head of magnetic or electric apparatus are styled philosophical instruments. Surely thought and not merely combination of woods, iron etc ought to be called the instrument of philosophy! The recent science of political economy has in England especially appropriated the name of philosophy". As quoted in Norbert Waszek. The Scottish Enlightenment and Hegel's Account of 'Civil Society'. (London: Kluwer Academic Publisher. 1988), 135

${ }^{15}$ The larger plan as propagated by Lancelot Wilkinson for Central and Northern India, pitched for a very careful transmission of European knowledge amongst the Indian subjects by also teaching them what was good and useful in their own system of which they previously knew nothing. Hence he suggested a rereading of the traditional India sources in accordance with the European scientific methodology. The publication of the book by Onkar Bhutt and the appointment of Bapu Deva Sastri as previously mentioned were in concurrence with this plan.

${ }^{16}$ Jabalpur station school of the company was also established in 1840 at the cost of Rs. 3000. English 
was placed in the same discipline as English under the superintendence of Mr. Rowe whose salary was increased to Rs. 300. A scheme of scholarship was introduced in the school according to which a junior scholar of the school was allowed to send to the Benares Central College on scholarship following a very strict criterion. ${ }^{17}$ However when these arrangements for the scholarship were made, first signs of resistance were noted amongst the students of Hindi. On $17^{\text {th }}$ November, Charles Reid forwarded to GCPI a letter from the scholars of vernacular department of the Sagar School that shocked the school authorities. In this letter the boys of the Hindi department registered their complaint to the school authorities on the non existence of Arabian and Sanskrit class suggesting the lack of which will eventually restrain them from obtaining a scholarship for the Benares Sanskrit College. These students identified themselves as boys of Hindvi School. Letter of Hindi students is shown in figure 2 below. ${ }^{18}$

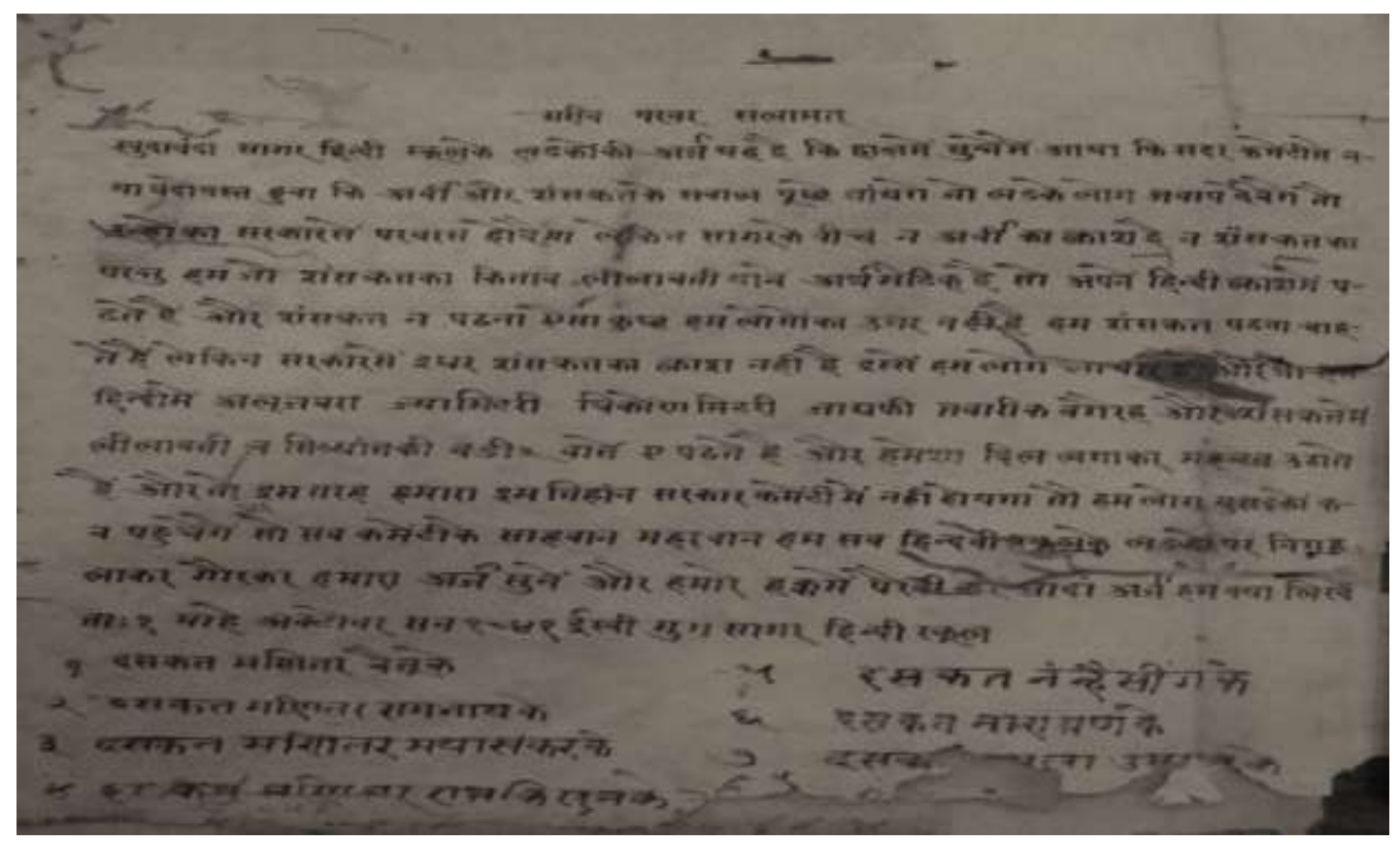

Figure2

The English classes at Allahabad School in the North Western Provinces had 7 Christian, 15 Muslim and 62 Hindu students. The English class was engaged in pursuing Milton's Paradise Lost, Poetical Reader no-4, Goldsmith's History of England, Cliff's Political economy, Luchman's Element's of Logic, Euclid's Elements, Algebra, Natural Philosophy, Geometry and the use of globe with composition and translation into the vernacular. Nagari (Hindi) and Urdu class were attached to the English department in 1841. An interesting set of questions and answers for the examination

department of the Jabalpur School contained 38 students and classes were divided into two (junior/ senior) under head master R. Stewart. The number of pupils recorded in the vernacular department attached with English department of the school was 124 with an increase of 2. Out of which 9 were Muslims and 115 Hindus.

17 The student was required to make following progress in his studies. English Reading: - To read with facility and correctness a piece of English prose selection from Dryden, Swift, Addison or Johnson. English Grammar: - To purse correctly and to correct the false grammar. History: - A knowledge of the leading facts of the histories of Rome, Greece, England and India. Geography: - He must understand the general form of the Earth its division into quarters, the division of quarter into countries, the name of the capital and principal cities of each country and the Principle Mountains and rivers. Arithmetic: - the simple and compound rules. A grammatical knowledge of Hindustanee or Bengali: - to be able to translate correctly from the English into the vernacular and from the vernacular into English. The candidate for scholarship was required to produce a certificate of good character from the local committee. The scholarship entitled was Rs. 30 for first two years and Rs. 40 for the next four years.

18 See, WBSA, GCPI Correspondence Jabbulpur and Saugor School $2^{\text {nd }}$ Nov. 1839 to $29^{\text {th }}$ Dec. 1841. Vol. 24. S1. No. 86/22. 881. This resistance may be the possible indication why the independent development of Hindi classes was immediately abandoned and provision was made to merge it with English department of the school under a European headmaster. 
conducted on October 1841 at Allahabad school in two disciplines of natural philosophy and history under the English classes and subsequently to be translated in the vernaculars aswell since the attachment of the vernacular classes was made, were as follows: -

Natural Philosophy and Astronomy $\left(2^{\text {nd }}\right.$ Class $)$

1. You have read that attraction is in proportion to meanness, as then the earth is nearer to the sun in one part of its orbit than in another, what operates to prevent its coming in contact with it?

2. The fixed stars are said to be suns of our system is attended by planets which are visible why then do we not see the planets belonging to the fixed stars?

3. Describe the position of earth's axis with regard to the plane of its orbit on the autumnal equine and on the $21^{\text {st }}$ Dec?

4. The centripetal force of the earth is nowhere so great as at the equator is this, the only reason why bodies weigh less there than in any other part of its surface?

5. On what part of the earth's surface do the sun's rays fall most obliquely?

6. One half of the sun is seen in certain situation and certain seasons to revolve round the horizon name the situation and seasons referred to?

7. Which has the greater velocity on inhabitant of London or one of Allahabad?

2. HISTORY

1. Is the Sanskrit language supposed to have sprung from the vernacular or the vernacular dialects from the Sanskrit? \{Answer- The vernacular dialect from Sungscrit\}

2. Is the religion which now prevails in India similar to that which was originally introduced by the Brahmuns? If not in what respect is it different? \{The religion which the Brahmins introduced did not teach the Hindus to worship idols. \}

3. Where are the Great War take place and between whom? \{In Cachutre between Pandwas and Koruas\}

4. What is said to have induced Vyas to compose the Mahabharat? \{Because Calidas the poet wrote Ramayain)

5. Are the Hindus of the present day essentially different from those of ancient times and give your authority for your answers? \{Because the customs which pervaded in ancient time are at present in full length in India.

6. Against what Mahometan General did Boppa defends Hillore? \{Inhumud bin Kasim\}

7. What Mahometan conqueror established the Mohametan rule in the N.West? \{Inhumud Gharey and chiefly his general Qutab.\}

8. What dynasty subdued the Deccans? \{Thilligy dynasty\}

9. In whose time did the provinces of Malva-Goozerat, Khandesh, Jaunpore revolt? \{In the reign of Muhummd Tagluek\}

10. Which of the province of India submitted in the most dastardly manner to the Mohemetan yoke and who added it to their territory? \{Bengal by Bukhtyar.\}

11. What King gave encouragement to the Affghans and who was the first of that race to sit on the throne of Delhi? \{Feroze Tugluk and Belol Lody was the first of that dynasty to sit on the throne of Delhi.\}

12. Who was the last Hindu King of Delhi? \{Prithviraj\}

13. Who attempted to remove the Mahometan capital of India to Dergurh and what induced the futile 
attempt? \{Julung as he went to conquer the deccan $\}.^{19}$

Another important question that was placed before the students of the Allahabad school for the prized essay competition was, "Whether the condition of the people of Hindustan was better at the time the country was under the Mughal dominion or whether it is better under the present time under the English rule". ${ }^{20}$ On $18^{\text {th }}$ February 1841 the GCPI also sanctioned to give scholarship to the pupils of Allahabad school in the Benares Central College. ${ }^{21}$

The activities of these schools established by GCPI were received with great amusement and excitement by native residents. The school authorities also were eager to invite local elites to attend annual prize distribution ceremonies and open door examinations were conducted in the presence of local elites. On January $4^{\text {th }} 1840$ such an annual examination of the Gazipur School was conducted and the money prize to the amount of 137 rupees was distributed for the best essays and the best specimen of writing and in calligraphy examination. Zamindars, Mahajans of Gazipur and surrounding areas were invited to witness the performance of students and they arrived in great number. But the ceremony conducted in English language made them disinterested in the proceedings of the ceremony. Azimgrah station had a branch school at Atraulia affiliated to the Azimgarh College. ${ }^{22}$ The branch school with about 60 pupils was established at Atraulia located on the Awadh border, by Mr. G. Norton in 1840 and was largely attended by the boys of surrounding villages. The annual examination of this branch school was conducted on $19^{\text {th }}$ January 1841 in the presence of judge, Captain Thomason Engineer, principle Sudder Amen of Gazipur, 9 deputy collectors, 4 Moonsiffs, 9 Zamindars and about 2000 landholders both European and natives of Azimgarh and neighbouring districts and of the adjoining Awadh territory and numerous native spectators. On this day the school received a donation of Rs. 720 with additional subscription of Rs. 71 from the present dignitaries. Mr. Fink, the superintendent of Azimgarh School stated that the liberal donations will enable the school to procure a number of books and philosophical instruments.

The English medium instruction at the Gazipur School was under Mr. Fowles and at Azimgarh College under Mr. Fink. At Gazipur since the introduction of English classes the Geometry classes taught in English at the school had good deal of attendance but the English poetry was considered unmusical by native students. On $17^{\text {th }}$ April 1841 the GCPI nominated Mr. Roberts to officiate as head master of this school during the absence of Mr. Fowles. Two months' salary to Mr. Roberts of Rs. 300 was paid in advance when he left Calcutta on $20^{\text {th }}$ April on board of the Magna Streamer. Under Mr. Roberts, history of Greece, Rome, England and India were translated from English to the vernacular (Urdu).

In Azimgarh College at the end of 1838 there were on the list of the school, 70 scholars and at the close of 1839, 223 scholars divided into three departments via, the vernacular, Sanskrit and English. These scholars were subdivided into 6 classes and these classes were generally subdivided in two or more divisions each. The studies of these pupils included a greater emphasis on translations from English. The report of the School mentioned that the books for the use of school were already being printed and Mr. Fink was preparing an Urdu work on physics and he published every fortnight an Urdu Akhbar with circulation of about 200 copies in Azimgarh and neighbouring districts as far as

19 GCPI Correspondence Gazipur and Allahabad School $3^{\text {rd }}$ January 1840 to $18^{\text {th }}$ December 1841 . Vol. no. 35. Sl. No. 32/99, 331 to 349 .

20 ibid, 71.

21 The qualification for obtaining the scholarship was: - I. English reading: - To read with facility and correctness a piece of English prose selected from Dryden, Swift, Addison or Johnson. II. English Grammar. III. History: - Acknowledgement of the leading facts of the histories of Rome, Greece, England and India. IV. Geography: - He must understand the general forms of the Earth, its divisions into quarters, the division into countries, the name of the capital and principal cities of each country and of the principal mountains and rivers. V. Arithmetic. VI. A grammatical knowledge of Hindee or Urdoo/ to be able to translate correctly from the English into vernacular and from the vernacular into the English. VII. That the candidate for the scholarship produces a certificate of good character from the LC. VIII. Value of scholarship: - 18 rupees.

22 38. $5 \mathrm{Km}$ Northwest of Azimgarh 
Allahabad and Saharanpur 'containing all the useful and interesting information for the people which can be collected' and was becoming popular. Besides teaching in the school Mr. Fink also had plan to establish a weekly lecture for the native society of the town on subjects of natural philosophy and general science. In penning down the experience received at the branch school in the process of native education it was observed that the school carried out the principles of the general plan of education sketched out in "Notes on Education" by the council of the Governor General by giving scientific instruction chiefly through the medium of the vernacular. The report predicted that the pupils of the school may not be able to smatter English but will turn out to be intelligent men, moral and useful members of the society and shall acquire the power of easily communicating their new ideas and information to their fellow-countrymen. The Hindi department carted pupils from the families of Mahajan, Bagals, and other traders' men. Their practice of profession was hereditary and they preferred studying Hindu arithmetic, book keeping and epistolary compositions. The new subjects that they were taught were geography and history. Pupils who were destined to be send to Benares College on scholarship were made to read more English than other students and were toiled in extracting squares, cubes and roots and to memorise names and places of Europe, Africa and America and were taught elements of Hindi grammar. The students of the Sanskrit department of the School were specifically taught the elements of Hindi grammar in addition to the course of studies in Sanskrit. It was purposed that they should study the Yate's book on natural philosophy. They were pursued to take up the studies in Hindi grammar and natural philosophy on the condition that they might be sent to Benares Sanskrit College on scholarship. To teach these pupils the salary of the Pundit of the Sanskrit department was fixed to that of Rs.16.

On the Urdu department Fink observed that there was no other department for which the school authority has to appease the wishes of the students and of the community in general, in regard to the subject of study. According to Fink the Persian and Arabic were studied by all members of the educated classes in Azimgarh as part of the liberal education and essential to the advancement in life (especially Persian). The Urdu was looked upon as a newly formed imperfect dialect, a key to knowledge of no kind and so easy as to be acquired only by use and conversation. In the view of Fink, the Arabic was much like the old Greek language with its own literature and Persian had many scientific works and extensive literature, while the Urdu had not more than dozen elementary works in science and history. Though Urdu had adherence in poetry but that for Fink, was of very little use in schools. The school had to endeavour hard in professing to teach Urdu and to discourage the study of Persian and Arabic. While the Persian and Arabic school books were excluded one by one from the department, very few Urdu text books were introduced to replace them. On the English language the general opinion according to Fink was similar to that on the Urdu. It was looked as the meagre language, the repository of no literature or science and the reason why any were studying it was to obtain a respectable employment in some court.

On $20^{\text {th }}$ March 1844 the responsibility of education shifted to the Government of NWP from Calcutta. James Thomason was appointed the Lt. Governor General of the NWP in 1843 to 1853. Two important developments took place during his tenure; one was the extension of school education to villages of NWP by bringing on board local elites (Zamindars and Talukadars) to bear responsibility and expenses of native education. The village councils, Zamindars, Talukadars were instructed to provide land for the construction of schools in respective villages and arrange for the payment of the salary of school masters. ${ }^{23}$ Second was the collusion of Sanskrit and English department at Benares College which formed a new department called Anglo-Sanskrit department. This department and Benares Sanskrit College in general emerged as an important site of corporation between the British and Indian intellectuals in the subsequent years. ${ }^{24}$ While the vernacular departments emerged as a site of contestation between Hindi and Urdu generally on the issue related to employment in government

23 Selection From the Records of the Government, NWP. Mr. Thomason's Despatches. Vol. I. Calcutta: Baptist Mission. 1856.

24 See, Micheal S. Dodson. Re-Presented for the Pandits: James Ballantyne, 'Useful Knowledge', and Sanskrit Scholarship in Benares College during the Mid-Nineteenth Century. 2002. Modern Asian Studies. Vol. 36. no.2. 257-298 
offices and courts especially in the latter half of the nineteenth century. The evolution of vernacular departments throughout the educational institutions located in the Central and North Western Provinces with all their short comings had long lasting impact in the creation and shaping of vernacular literature and education in NWP in later decades of the $19^{\text {th }}$ century. Most of the literati in both the vernaculars studied in these educational institutes, including major figure such as Harish Chandra (1850-1885) and a considerable number of his fellow writers who did pioneering work in the formation of modern Hindi literature.

AUTHOR'S BIOGRAPHY

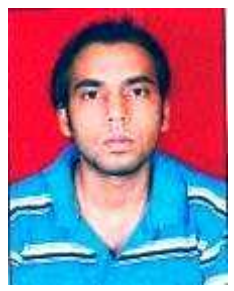

Sumeet Tanwar, is pursuing PhD at Department of English, University of Delhi. The title of the research topic is Bharatendu Mandal: An Enquiry into the Socioreligious and Linguistic Transformation in 19th century North India

Citation: Sumeet Tanwar. "Vernacular Education in India: British Education Policy in 1840" International Journal of Humanities Social Sciences and Education (IJHSSE), vol 4, no. 12, 2017, pp. 109-117. doi: http://dx.doi.org/10.20431/2349-0381.0412014.

Copyright: () 2017 Authors. This is an open-access article distributed under the terms of the Creative Commons Attribution License, which permits unrestricted use, distribution, and reproduction in any medium, provided the original author and source are credited. 